Nina SIEMIENIUK, PhD, Professor of the University of Bialystok

Faculty of Economics and Management, University of Bialystok

e-mail: n.siemieniuk@uwb.edu.pl

ORCID: 0000-0002-8819-1301

Agnieszka ZALEWSKA-BOCHENKO, PhD

Faculty of Economics and Management, University of Bialystok

e-mail: a.zalewska-bochenko@uwb.edu.pl

ORCID: 0000-0002-7382-0064

Lukasz SIEMIENIUK, PhD

Faculty of Economics and Management, University of Bialystok

e-mail: 1.siemieniuk@uwb.edu.pl

ORCID: 0000-0002-0133-1472

DOI: $10.15290 /$ oes.2018.04.94.01

\title{
FUNCTIONALITY OF IT FINANCIAL AND ACCOUNTING SYSTEMS IN THE PRACTICE OF POLISH ENTERPRISES
}

\begin{abstract}
Summary
The development of technologies and innovative solutions in the field of information transfer has a significant impact on the functioning of enterprises. Accounting is treated as an organized system of collecting and processing information affecting the enterprise. The aim of the paper is to indicate the important elements that support the organization of financial and accounting work in the company. The analyses were based on the data and research of IT financial and accounting systems. The analysis of the collected literature on the subject and the synthesis of knowledge included there was helpful in implementing this method. It has been hypothesized that the implemented IT systems in enterprises significantly support accounting and finance and bring potential benefits from the use of such software by enterprises. The paper shows that the role of financial and accounting systems in modern enterprises is becoming more and more important and irreplaceable. Thanks to computer systems it is possible to perform the tasks entrusted to employees quickly and efficiently.
\end{abstract}

Key words: financial and accounting system, financial and accounting programs, IT financial and accounting system

JEL classification: 033 


\section{Introduction}

Finance and accounting are the domains that over the years have elaborated their own principles and techniques which facilitate their functioning and ensure the consistency of the entire system connected with the functioning of economic entities. Economic records, which have been known since the times of ancient Mesopotamia, have been present in enterprises despite numerous transitions. Previously records were kept on paper, whereas nowadays the basic instruments of each accountant are a computer and IT system. The development of IT technologies enabled easier method of storing the documentation of enterprises and facilitated the work of accountants. However, the number and accessibility of the available computer programs that are useful for making financial and book-keeping records may appear to be overwhelming.

The aim of the paper is to point at the essential elements facilitating the organization of financial and book-keeping work within an enterprise. On its basis the following thesis has been formulated: Without electronic systems the financial and book-keeping work would not be effective. The paper discusses the functions that the basic financial and accounting system ought to perform and shows various options of IT systems managing the economic record-keeping of enterprises.

The functionality of IT FA (financial and book-keeping) systems in this paper implies its practicality, usefulness, comfort and convenience of usage. Owing to this the applied research method implied the analysis of the available data and literature. The interest in a particular FA system in the area of the accounting theory results from its popularity, functionality and from the possibility of its application in the didactic process at universities.

\section{Accounting versus financial and accounting system}

Proper management constitutes the basis of the functioning of each economic entity. The condition of efficiency and expected benefits is adequate and reliable information and data.

One of the key information conduits of an enterprise is accounting. The purpose of this domain is to provide knowledge that will enable proper evaluation of an enterprise, including the economic processes and phenomena occurring there as well as the management of them.

The effectiveness of data submitted by accounting depends on the degree of adjusting the organizational structure of an enterprise and its strategy as well as on the interrelated problems of the decision-making type [Ebisch-Stenzel, 2013, p. 35].

As an information system accounting may be divided into [Kiziukiewicz, 2003, p. 267]:

- financial accounting regulated by the national and international regulations and addressed chiefly at the external recipients; used also for preparing the internal reports; 
- management accounting resulting from the enterprise's information needs and defined as the system of storing, elaborating and presenting information referring to the past and future economic phenomena.

The accounting information system ought to [Nowak, 2003, p. 446]:

- provide information for various recipients;

- provide information that is useful from the perspective of recipients;

- be an integrated system that combines various subsystems;

- be subject to information support.

The selection of the financial and accounting system is one of the key decisions made within the strategy of a certain enterprise. It has impact both on the actions of the financial and accounting department, but also affects the effective cooperation with more important trade partners. Therefore, the selection of the system ought to be well thought of or a specialized consulting company ought to be responsible for it. Additionally, the systems used by our contractors should be taken into account so as to ensure effective exchange of information.

\section{IT system within an enterprise}

The condition of proper functioning of an enterprise and its management is the access to the knowledge of specialist terms. The satisfaction of needs connected with necessary knowledge is possible thanks to the effective information system. The availability of this facility is possible owing to the development of the computer technology. The existence of a certain system is supposed to provide necessary information concerning the enterprise management.

Nowadays the most frequently used systems are integrated systems that are useful for the comprehensive service of all the spheres of an enterprise. Integrated systems are based on data concerning particular activity spheres [Ebisch-Stenzel, 2013, p. 37].

The characteristic features of integrated systems include [Grodziński, 2005, pp. 12-13]:

- complexity which is visible in all the spheres of an enterprise's activity;

- integration of data and processes taking place both within the system and including the surrounding;

- flexibility which enables the adjustment of the applied hardware and software solution while installing and activating the system and also enables its adjustment to the changeable conditions within the organization and the impact of the surrounding;

- openness that means the capability of expanding the system using new modules,

- IT support of the decision-making processes;

- technological advancement that guarantees conformity with the current standards related to computer software and hardware and also enables free migration of data;

- compliance with the applicable regulations. 


\subsection{IT financial and accounting system}

The key element of integrated IT is the financial and accounting system. With the years passing by and along with the technological development such system from the instrument serving the recording of economic events have been transformed into the system that in terms of its activity scope supports the management board as regards making decisions concerning the functioning and development of an enterprise.

The scheme of financial and accounting system

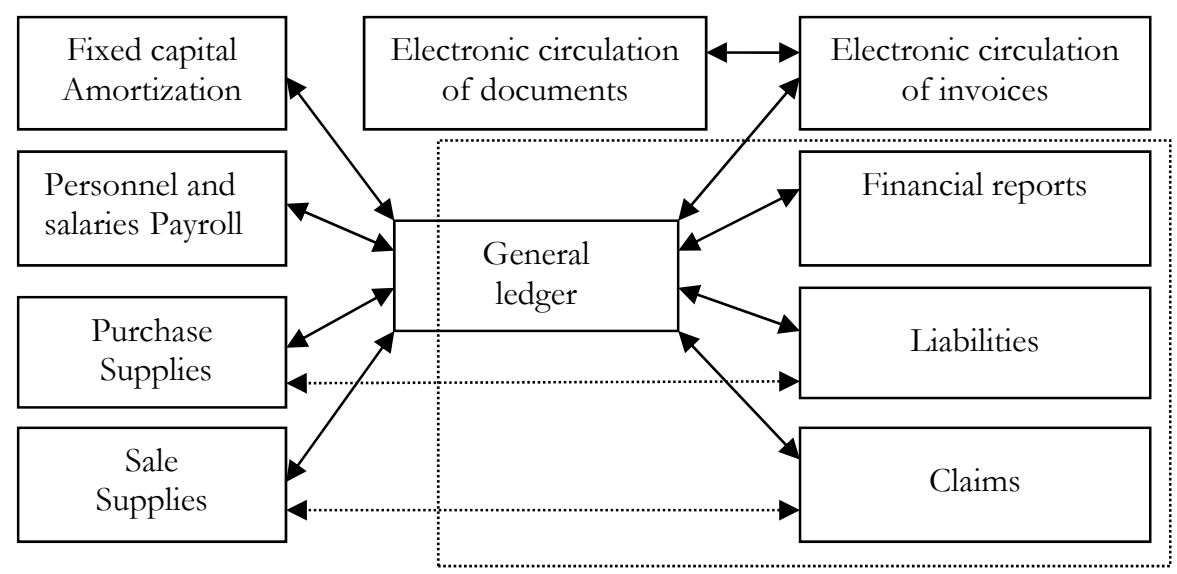

Source: [Ebisch-Stenzel, 2005, p. 281].

The IT financial and accounting system is composed of modules that work together. Their combination enables the access to the data registered in one of the modules from the level of other parts of the system.

The main functions of the financial and accounting system include [Kunz, Tymińska, 2014, pp. 54-55; Andrzejewski et al., 2004, pp. 16-17; Chojnacka, Niepsujewicz-Misiek, 2005, p. 102]:

- informative function that provides information for the needs of external entities (among others: financial institutions and offices) as well as internal ones (the owners, management board and employees) that may be useful for the assessment of the way a certain unit is functioning. Thanks to the application of IT financial and accounting systems it is possible to provide data with selected frequency and with selected level of precision. The basing of information on the computer record contributes to the fact that it includes less mistakes that may be formed in the process of manual setting of reports and status reports. It needs emphasizing that the users of IT systems dedicated for small and medium-sized enterprises attach much 
importance to its functionality in terms of tax reports (PIT and CIT tax returns);

- stimulative (management) function that in a systematic manner provides data in the form of indicators, reports and status reports; its purpose is to motivate the management board so that the results get improved in the future, which may support the optimum allocation of the enterprise's resources and their effective application. Accounting stimulates the effective usage of the owners' wealth in order to increase the enterprise's value. The possibility of obtaining management information without delays ought to be considered as one of the greatest advantages of conducting the accounting records using computer financial and accounting systems;

- communicative function which enables timely supply of information regarding a certain degree of detail and precision, the access to information is simple and may be obtained at any time;

- reporting function which enables preparation of financial reports required by law, their main addressees are external recipients [Chojnacka, Niepsujewicz-Misiek, 2005, p. 102];

- controlling function which is manifested in the possibility of protecting and securing the entity's property from destruction or embezzlement. IT systems that support accounting may to a considerable degree have impact on the reduction of the number of thefts because they more frequently require the specification of responsibility for particular elements of the enterprise's assets and enable accurate monitoring of the circulation of the assets' components. "Paper" accounting has not ensured such large possibilities as regards the realization of the controlling function of accounting [Andrzejewski et al., 2004, pp. 16-17];

- analytical function enabling the analysis and interpretation of information generated by accounting, on the basis of which there is assessed the economic, property and financial situation of the economic entity; it enables the evaluation of the effectiveness of using resources, revealing of irregularities and making rational decisions;

- statistical function where accounting constitutes the source of information for the organs of public statistics, whereas the statistical function facilitates and improves the preparation of reports and status reports as well as the collection of information. The additional advantage of using modern methods of accounting reports is the possibility of submitting statistical reports in an electronic version [Kunz, Tymińska, 2014, pp. 54-55].

\section{The types of financial and accounting systems}

Financial and accounting systems differ from one another in terms of the target group of recipients and the reports prepared by them. 
The minimum requirements towards the computer systems that support the enterprise's accounting were specified in the Accounting Law. However, there are no procedures that enable specification whether there requirements have been met in the presently used IT systems. A good practice is when the producers of IT software used in accounting gain the recommendation of the Accountants Association in Poland (SKwP). The list of financial and accounting programs, which are recommended by SKwP, was presented in table 1 [Kunz, Tymińska, 2014, p. 52].

TABLE 1

Financial and accounting programs recommended by the Accountants Association in Poland

\begin{tabular}{|c|c|c|c|}
\hline No. & $\begin{array}{c}\text { The name of the recommended } \\
\text { product }\end{array}$ & $\begin{array}{l}\text { The date of } \\
\text { recommen- } \\
\text { dation }\end{array}$ & $\begin{array}{l}\text { The company } \\
\text { applying for } \\
\text { recommendation }\end{array}$ \\
\hline 1 & SIMPLE-FK, version 4.50 (a) & $4^{\text {th }}$ March 1996 & SIMPLE \\
\hline 2 & $\begin{array}{l}\text { SYSTEM FINANSOWO-KSIĘGOWY } \\
\text { FKX version 7.24.026. }\end{array}$ & 22 nd June 1998 & $\begin{array}{l}\text { Prokom Softwore } \\
\text { Sp. z o.o. Gdynia }\end{array}$ \\
\hline 3 & $\begin{array}{l}\text { FIKS system finansowo-księgowy, } \\
\text { version } 8.14 \text {. }\end{array}$ & $\begin{array}{l}14^{\text {th }} \text { September } \\
1998\end{array}$ & $\begin{array}{l}\text { Makcrosoft S.A. } \\
\text { Warszawa }\end{array}$ \\
\hline 4 & ADAPTIX/FK, wersja 108A & $\begin{array}{l}\text { 19th September } \\
2000\end{array}$ & $\begin{array}{l}\text { „MaWi” Ag. Informat. } \\
\text { Kraków }\end{array}$ \\
\hline 5 & $\begin{array}{l}\text { IMPULS-BPSC, podsystem FINANSE } \\
\text { KSIĘGOWOŚĆ-KOSZTY, version } 4.2\end{array}$ & $\begin{array}{l}19^{\text {th }} \text { December } \\
2000\end{array}$ & $\begin{array}{l}\text { Biuro Projektowania } \\
\text { Systemów Cyfrowych } \\
\text { BPSC Katowice }\end{array}$ \\
\hline 6 & „NOVUM BANK”, version 4GL & $\begin{array}{l}1^{\text {th }} \text { December } \\
2000\end{array}$ & $\begin{array}{l}\text { Zakład Usług Infor- } \\
\text { matycznych NOVUM } \\
\text { Sp. z o.o. Łomża }\end{array}$ \\
\hline 7 & $\begin{array}{l}\text { SAP R/3 - moduły FI (GL, AP,AR, } \\
\text { AA, BL) + CO (OM-CEL, OM-CCA, } \\
\text { OMOPA, OM-IS, PC-OBJ) version } \\
\text { 4.6C }\end{array}$ & $20^{\text {th }}$ July 2001 & $\begin{array}{l}\text { SAP Polska Sp. z o.o. } \\
\text { Warszawa }\end{array}$ \\
\hline 8 & IFS FINANSE & $\begin{array}{l}10^{\text {th }} \text { September } \\
2001\end{array}$ & $\begin{array}{l}\text { Indutrial\&Financial } \\
\text { System }\end{array}$ \\
\hline 9 & $\begin{array}{l}\text { „System Ekonomiczno-Finansowy } \\
\text { ProFIN”, version } 3.30\end{array}$ & $\begin{array}{l}10^{\text {th }} \text { September } \\
2001\end{array}$ & Pro-Test S.A. Warszawa \\
\hline 10 & SKOP-FK, version 6.1. & 14th May 2002 & $\begin{array}{l}\text { Bytomska Spółka } \\
\text { Informatyczna COIG } 4 \\
\text { Sp. z o.o. Bytom }\end{array}$ \\
\hline 11 & $\begin{array}{l}\text { „Finanse i Księgowość - forte”, version } \\
5.00\end{array}$ & $4^{\text {th }}$ February 2003 & MATRIX Pl. Warszawa \\
\hline 12 & $\begin{array}{l}\text { „System Zarządzania Firmą } \\
\text { DIGITLAND ENTERPRISE”, moduł } \\
\text { Finanse i Księgowość, version } 15.05\end{array}$ & $\begin{array}{l}18^{\text {th }} \text { November } \\
2003\end{array}$ & $\begin{array}{l}\text { PHU „DIGIT-LAND } \\
\text { W. Wierzba Kraków }\end{array}$ \\
\hline 13 & SAP Business One, version 7.5 & $31^{\text {st }}$ August2004 & $\begin{array}{l}\text { SAP Polska Sp. z o.o. } \\
\text { Warszawa }\end{array}$ \\
\hline
\end{tabular}


Functionality of it financial and accounting systems in the practice ...

\begin{tabular}{|c|c|c|c|}
\hline No. & $\begin{array}{c}\text { The name of the recommended } \\
\text { product }\end{array}$ & $\begin{array}{l}\text { The date of } \\
\text { recommen- } \\
\text { dation }\end{array}$ & $\begin{array}{l}\text { The company } \\
\text { applying for } \\
\text { recommendation }\end{array}$ \\
\hline 14 & $\begin{array}{l}\text { RAMZES - Księgi Handlowe, version } \\
\text { 01.25.01. }\end{array}$ & $\begin{array}{l}16^{\text {th }} \text { November } \\
2004\end{array}$ & $\begin{array}{l}\text { Ramzes Sp. z o.o. } \\
\text { Warszawa }\end{array}$ \\
\hline 15 & $\begin{array}{l}\text { WF-FaKir, wersja } 6.10 .5 \text { and WF-bEST, } \\
\text { version } 6.10 .3\end{array}$ & $15^{\text {th }}$ February 2005 & WA-PRO Sp. z o.o. \\
\hline 16 & SAP Business One, version 7.6 & 15th February 2005 & $\begin{array}{l}\text { SAP Polska Sp. z o.o. } \\
\text { Warszawa }\end{array}$ \\
\hline 17 & CDN OPT!MA, version 8.6. & 23rd August 2005 & $\begin{array}{l}\text { COMARCH SA } \\
\text { Kraków }\end{array}$ \\
\hline 18 & $\begin{array}{l}\text { RAMZES Amortyzacja, version } \\
\text { 05.28.06 }\end{array}$ & $\begin{array}{l}22^{\text {nd }} \text { November } \\
2005\end{array}$ & $\begin{array}{l}\text { Ramzes Sp. z o.o. } \\
\text { Warszawa }\end{array}$ \\
\hline 19 & $\begin{array}{l}\text { SIMPLE.ERP, moduł Finanse } \\
\text { i Księgowość }\end{array}$ & $16^{\text {th }}$ January 2007 & $\begin{array}{l}\text { SIMPLE. S.A. } \\
\text { Warszawa }\end{array}$ \\
\hline 20 & EuroBankNet w wersji e06 & $16^{\text {th }}$ January 2007 & $\begin{array}{l}\text { SoftNet Sp. z o.o. } \\
\text { Kraków }\end{array}$ \\
\hline 21 & $\begin{array}{l}\text { SIMPLE.ERP w zakresie modułu } \\
\text { Majątek Trwały w wersji 5.00a }\end{array}$ & $4^{\text {th }}$ September 2007 & $\begin{array}{l}\text { SIMPLE S.A. } \\
\text { Warszawa }\end{array}$ \\
\hline 22 & IMPULS, version 5 & $\begin{array}{l}\text { 17th December } \\
2007\end{array}$ & BPSC S.A. Chorzów \\
\hline 23 & Oracle e-Business Suite, version 12 & $\begin{array}{l}23^{\text {rd }} \text { September } \\
2008\end{array}$ & $\begin{array}{l}\text { Oracle Polska Sp. z o.o. } \\
\text { Warszawa }\end{array}$ \\
\hline 24 & IFS Applications version 7.5 & 20th April 2009 & $\begin{array}{l}\text { Industrial\&Financial } \\
\text { Sytems Poland Sp. } \\
\text { z o.o. Warszawa }\end{array}$ \\
\hline 25 & $\begin{array}{l}\text { Papirus SQL dla modułów: Finansowo } \\
\text { Księgowy version } 2.07 .10 .00\end{array}$ & 19th March 2013 & SOFHARD S.A. Płock \\
\hline 26 & IFS Applications version 8 & $8^{\text {th }}$ October 2013 & $\begin{array}{l}\text { Industrial\&Financial } \\
\text { Systems Poland Sp. } \\
\text { z o.o. Warszawa }\end{array}$ \\
\hline
\end{tabular}

Source: [Kunz, Tymińska, 2014, pp. 52-53].

The leading supplier of the financial and accounting system in Poland for small and medium-sized enterprises is Sage. Sage purchased the software termed as Symfonia (which had been created in the early 1990s) from MATRIX. Since that time the software has been expanded and gained such new modules as: Sage Symfonia Finanse i księgowość, Sage Symfonia Start 2.0, Mała Księgowość, Sage Symfonia 2.0 or Środki Trwałe.

The offer referred to as Sage Symfonia Finanse i Księgowość is addressed at the companies having full accounting. It enables the record keeping of all the key economic operations.

The main advantage of the system include, among others: simple adjustment of the program to the enterprise's needs, data safety, simple service, the current control of assets and liabilities, summaries, reports and useful analytical graphs [Sage, 2018]. Symfonia is useful in the realization of all the essential accounting operations: start- 
ing from establishing accounts and booking documentation, via automatic closing balance, full settlements and finishing with the creation of status reports, summaries and reports.

Another leader providing accounting systems is Comarch. The company offers 4 types of programs adjusted to the needs of enterprises. These are software types adjusted for trade and service companies and trade networks, for small and mediumsized enterprises of production, trade and service type, for small and medium-sized enterprises and accounting offices as well as the mobile program for small companies.

The company Sputnik Software created the System SJO BeSTi@ on the demand of the Ministry of Finance. The program aims at improving the finance management of local territorial units. It is useful for the organizational service units of local territorial units to perform their tasks that include [Dokumentacja usytkownika, 2018]:

- preparing unit reports in monthly and quarter reporting periods ;

- preparing unit balances of budget units, self-government budget undertakings, the total balance comprising data resulting from self-government balances of budget units and self-government budget departments, balances of LTU budget and consolidated balance;

- $\quad$ planning the budget starting from the stage of preparing the budget project up to all the modifications;

- $\quad$ exchanging data between organizational units and the local territorial unit.

Another example of the financial and accounting system used in small and medium-sized enterprises is the system of YUMA. The company offers the program YUMA FeliKS, which was improved in the version YUMA FK Plus. The system is used in case of conducting integrated accounts in the enterprise. The functioning of this system is adjusted to the accepted principles of the accounting policy which in a very precise way define the manner and scope of recording booking particular types of economic events. The system's purpose is to keep the chronological order of the events and enable the users to control the prepared documents. Additionally, it facilitates the generation of the Standard Audit File on the basis of the collected data. It has the elaborated interface and configuration possibilities owing to which the program is user-friendly - it improves and facilitates the user's work in the accounting sphere. By means of a large scope of configurations the program may be applied for many branches of business activity [Yuma, 2018].

Another system that enables comprehensive accounting is the program R2fk. It enables a company comprehensive accounting and additionally as the option a company's accounting may adopt the form of revenue and expenditures ledger or a revenue account. It includes many additional modules enabling conducting all the required records and full accounting of a company and its owners with the inland revuenue [Opis programu, 2018].

The professional financial and accounting systems for small and medium-sized companies include also Rewizor GT. The program was created on the basis of the Accounting Law and is adjusted to the requirements of the European Union. It is 
dedicated for both self-employed book-keepers and accountancy offices [Rewizor GT, 2018].

The program was followed by the program referred to as Rewizor nexo PRO. This modern program is dedicated for full accounting. It constitutes the expanded version of Rewizor nexo - created for those demanding flexible and open financial and accounting system. It enables, among others, the usage of multi-level card-index accounts, the creation of the company's own reports and prints, the own description of economic events e.g. additional transactions using VAT or the settlement of commitments in installments or booking of them using own types.

Rewizor nexo PRO is the part of InsERT nexo PRO - the integrated package including also: Subiekt nexo PRO - the system of sale service and warehouse management, Rachmistrz nexo PRO - program for simplified accounting, Gratyfikant nexo PRO - system of personnel and remunerations and Gestor nexo PRO - system for the management of relations with customers [Rewizor nexo PRO, 2018].

There may be isolated also the module termed as Trading Book which is allocated for preparing full accounting of enterprises: national, private, cooperatives, non-profit organizations as well as funds. It enables the realization of various types of accounting operations, starting from the creation of the plan of accounts and not complicated accounting of documents, starting from clearing and settlement up to automatic formation of a full balance table as well as the calculation of profits and losses, various types of declarations as well as statements and reports. The system functions either on its own or in combination with other RAKSSQL modules, with which it creates the whole. The system cooperates with the bank settlement systems Home Banking, generates the application and settlement documents for inland revenues and ZUS [Raks, 2018].

Program 360 Księgowość is an innovative program that enables many companies to have full accounting in one place. It was elaborated by accounting experts. The system is characterized by such properties as: the simplicity of operations and usage, the guarantee of compliance with the Accounting Law, automatic updates, professional and free technical assistance. It is worth emphasizing also that the aforementioned program offers accounting for the unlimited number of companies without additional fees. The system was accepted by 38759 companies [Program ksiegony, 2018].

\section{Conclusions}

Professional financial and accounting systems guarantee numerous instruments and functions that are useful for assessing the state of the company. Owing to this it is possible to prepare reports regarding the commitments and liabilities towards single contractors and all the entities that a certain unit cooperates with. Furthermore, the appropriate system, on the basis of the documents regarding purchase or sale enable netting the mutual commitments and liabilities within one or several entities. These are the so-called one or multi-sided compensations. 
These systems not only serve reporting economic operations, but also enable the effective management of the costs. The available instruments guarantee the analysis of revenues and costs in various perspectives, e.g. in terms of the type or place of formation [Asiston oprogramowanie, 2017].

Accounting plays a crucial role in the scale of economic entities and the entire economy. It constitutes the source of important information for both the management board of the enterprises and for such state institutions as IRS or ZUS. Most processes connected with accounting take place using computers and financial and accounting programs. The versatile usage of Internet and modern technologies results in designing faster, complex and integrated IT systems necessary for accounting. In their attempt to be innovative on the market, enterprises constantly introduce new software that not only accelerates and facilitates management for enterprises, but also contributes to substantial savings and the increase of competitiveness on the market.

The aforementioned process enables the formulation of the assumption that the market of IT financial and accounting systems will develop in the future and has large growth potential, which constitutes the basis of further discerning study in this subject.

\section{References}

Andrzejewski M., Jonas K., Młodkowski P., 2004, Zastosowanie technik komputeronych w rachunkowości, Oficyna Ekonomiczna, Kraków.

Asiston oprogramowanie, http://www.asiston.pl/oprogramowanie/systemy-finansowoksiegowe [date of entry: 15.10.2017].

Chojnacka A., Niepsujewicz-Misiek B., 2005, Podsystem finansowo-ksiegony, [w:] Architektura zintegrowanego systemu informatycznego zarzadzania, Bytniewski A. (red.), Wydawnictwo Akademii Ekonomicznej im. Oskara Langego we Wrocławiu, Wroclaw.

Dokumentacja usiytkownika, http://pomoc.sputniksoftware.com/pliki/instalki/Bestia/ SJODokumentacjaUzytkownika.pdf [date of entry: 16.01.2018].

Ebisch-Stenzel M., na podstawie: Wyraz W., 2005, System finansowo-ksiegony, [w:] Wstep do systemón informacyjnych zarz̨adzania w przedsiebiorstwie, Nowicki A. (red.), Wydawnictwo Politechniki Częstochowskiej, Częstochowa.

Ebisch-Stenzel M., 2013, Kryteria wyboru finansowo-ksiegowego i jego rola w zarz̨qdzaniu przedsiebiorstwem, „Zeszyt naukowy Uniwersytetu Szczecińskiego”, nr 765, „Finanse, Rynki Finansowe, Ubezpieczenia", nr 61.

Grodziński R., 2005, Ogólne informacje o strukturze ZSIZ, [w:] Architektura zintegrowanego systemu informatycznego zarzadzania, Bytniewski A. (red.), Wydawnictwo Akademii Ekonomicznej im. Oskara Langego we Wrocławiu, Wrocław.

Kiziukiewicz T., 2003, Racbunkowość zarzadcza jako instrument zarzadzania, [w:] Zarzadcze aspekty rachunkowości, Kiziukiewicz T. (red.), Polskie Wydawnictwo Ekonomiczne, Warszawa. 
Kunz B., Tymińska A., 2014, System informatyczny w rachunkowości i jego rola w swietle ustawy o rachunkowości, Uniwersytet Ekonomiczny we Wrocławiu, Wrocław.

Nowak E., 2003, Rachunkowosśc zarzadcza, [w:] Rachunkowość Przewodnik, Cebrowska T. (red.), Economics, Wrocław.

Opis programu, http://www.reset2.pl/oferta/standard/r2fk/opis-programu [date of entry: 17.01.2018].

Program ksiegony, https://www.360ksiegowosc.pl/program-ksiegowy-dla-ksiegowych [date of entry: 17.01.2018].

Raks, https://www.raks.pl/program-ksiegowy [date of entry: 17.01.2018].

Rewizor GT, https://www.insert.com.pl/programy_dla_firm/ksiegowosc_i_finanse/ rewizor_gt/opis.html [date of entry: 17.01.2018].

Rewizor nexo PRO, https://www.insert.com.pl/programy_dla_firm/ksiegowosc_i_ finanse/rewizor_nexo_pro/opis.html [date of entry: 17.01.2018].

Sage, http://www.sage.com.pl/produkty/obszar-finansowo-ksiegowy/ksiegowosc/ sage-symfonia-finanse-i-ksiegowosc/szczegoly\#link0 [date of entry: 15.01.2018].

Yuma, http://www.yuma.pl/produkty/feliks/ [date of entry: 17.01.2018]. 